\title{
Visualiseerimise rollist fraseologismi mõistmisel reklaamide näitel ${ }^{1}$
}

\author{
Anneli Baran
}

Teesid: Fraseologismide puhul on tavaks rääkida nende kujundlikkusest või piltlikkusest. Mida tuleks aga mõista piltlikkuse all täpsemalt? Keelelise üksuse puhul saab seda mõista omadusena ärgitada visuaalset kujutlust. Nii ongi suure osa fraseologismide otsene tähendus sedavõrd piltlik, et väljend on visuaalselt ettekujutatav. On ilmne, et individuaalsed visualiseeringud võivad aidata kaasa tundmatu väljendi mõistmisele. Seda, et keelekasutajad võivad fraseologismi mõtestamisel teadlikult n-ö tõukuda kujutluspiltidest, kinnitavad ka psühholingvistilised eksperimendid. Vaatlen lähemalt väljendi visualiseerimist kui vahendit oma sõnumi edastamiseks reklaamides ja nende vastuvõttu ehk mõistestamist.

Märksõnad: fraseologismid, ikoonilisus, mentaalne leksikon, motivatsioon, piltlikkus

${ }^{1}$ Artikkel on valminud sihtfinantseeritava teema SF 0030181s08 "Folkloori narratiivsed aspektid. Võim, isiksus ja globaliseerumine" ja riikliku programmi "Eesti keel ja kultuurimälu 2009" projekti EKKM09-150 "Eesti kõnekäändude ja fraseologismide andmebaas ja fraseologismide allikpublikatsioon "Monumenta Estoniae Antiquae" sarjas" toel. 


\section{Fraseologismi motivatsioonist ${ }^{2}$}

Fraseoloogilise keeleüksuse olemusest rääkides on tavaks rõhutada talle iseloomulikke omadusi nagu püsivus, piltlikkus/kujundlikkus, motivatsioon, idiomaatilisus. Samas tuuakse peaaegu alati esile nende parameetrite suhtelisust, subjektiivsusfaktori mõju. Seega pole tegemist ühtemoodi kõigi fraseloogiliste üksuste kohta käibivate karakteristikutega.

Fraseoloogiauurimise keskseks mõisteks on juba üle poole sajandi olnud kahtlematult motivatsioon. Peaaegu sama kaua on kestnud ka diskussioon motiveerituse (põhjendatuse) mõiste üle fraseoloogia-alases uurimistöös. Motiveerituse kriteeriumi, mille tõi fraseoloogiliste üksuste klassifikatsiooni vene keeleteadlane akadeemik Viktor Vladimirovitš Vinogradov, peetakse tänapäeva fraseoloogias enamasti subjektiivseks, kaldudes koguni jätma seda kõrvale, kui analüüsiks vähesobivat. Kuna aga tegu on siiski olulise mõistega, mis aitab mõista fraseologismi olemust, peatun sellel veidi pikemalt.

Alates Vinogradovist eristatakse motiveerituse kriteeriumi alusel laias laastus kahesuguseid fraseologisme: fraseoloogilised sulamid e läbipaistmatud fraselogismid ja fraseoloogiliselt terviklikud ühendid e läbipaistvad fraseologismid. Need kaks põhitüüpi sisaldavad üksusi, mis eristuvad üksnes motiveerituse kriteeriumi alusel. Esimesed on motiveerimata, teised "evivad ebaselget vihjet motiveeritusele ja semantilisele jagatavusele" (Vinogradov 1947, 352-353). Siinkohal tulebki mängu subjektiivsus, sest väljaarvatud vähesed ilmselged juhud, pole motiveerituse tase tihtipeale mõõdetav keeleliste vahenditega.

Fraseoloogiauurimises käibiv motiveerituse definitsioon pärineb fraseoloog Harald Burgerilt: "Motiveerituse all mõeldakse seda, kui fraseologismi tähendus on mõistetav sõnaühendi vaba tähenduse või komponentide tähenduste kaudu" $(2003,66)$. Ka Burger toonitab sarnaselt Vinogradoviga motiveerituse lahutamatust semantilisest idiomaatilisusest: mida tugevamalt on fraseologism motiveeritud, seda nõrgem on tema idiomaatilisus (ja vastupidi). Seega on motivatsioon pöördvõrdelises suhtes idiomaatilisusega, ning ühtlasi vältimatu mõiste - ühe omadust mõistetakse/mõtestatakse teise kaudu. Burger käsitab motiveerituse taset kui märgiahela eritasemelist

${ }^{2}$ Antud teoreetiline osa artiklist põhineb siinkirjutaja 2011. aasta märtsis kaitstud doktoritööl (vt Baran 2011). 
suhet terviku ja selle üksikute komponentide vahel (1973, 26jj). See märgijada võib olla motiveeritud või motiveerimata. Esimesel juhul on kogutähendus n-ö tuletatav elementide tähendustest, kuna vormilise ja semantilise struktuuri vahel valitseb isomorfsus, teisel juhul mitte. Idiomaatika puhul nähtub sel juhul, et idioomid kitsamas mõttes on mittemotiveeritavad sõnajadad, idioomid laiemas mõttes on nõrgalt motiveeritud, ning täielikult motiveeritavad jadad ei ole idiomaatilised. Seega - mida nõrgemalt on sõnajada motiveeritud, seda idiomaatilisem ta on. Samas toonitab ka Burger, et mitte ainult motivatsiooni ennast, vaid ka motivatsiooni ja idiomaatika suhet mõistavad keelekasutajad erinevalt.

Vinogradovi ja Burgeri kõrval on fraseologismide motivatsiooni problemaatikasse üritanud selgust tuua veel kaks fraseoloogiauurijat - Dmitri Dobrovolski ja Elisabeth Piirainen. Nende kahe ühistööna on valminud kolm monograafiat: "Symbole in Sprache und Kultur. Studien zur Phraseologie aus kultursemiotischer Perspektive" (1996), "Figurative language: cross-cultural and cross-linguistic perspectives" (2005) ja “Zur Theorie der Phraseologie. Kognitive und kulturelle Aspekte" (2009).

Oma käsitluse fraseologismi motivatsiooni eri tüüpidest rajasid nad semiootilistele mõistetele arbitraarsus, ikoonilisus ja sümbolilisus. ${ }^{3}$ Ehk nii nagu on sedastanud Dobrovolski ja Piirainen (2005, 183jj): kuigi kujundlike üksuste loome on käsitletav spontaanse ja ennustamatuna, ei ole see täielikult meelevaldne, kuna osaliselt määratlevad seda teatud seaduspärasused. Olulisimana tõstaksin esile nende väidet, et konventsionaalsed kujundlikud üksused on samaaegselt arbitraarsed ja mittearbitraarsed (Piirainen 2005, 184jj). Suhestades arbitraarsuse kognitivistikast pärineva kontseptuaalse mõistestamise teooriaga, leidsid nad, et fraseologismid on arbitraarsed selles mõttes, et kuigi kujundliku üksuse moodustumist määrab teatud kontseptuaalne struktuur, ei ole nn semantiline tulemus täielikult ennustatav - ennustatavuse tase sõltub motivatsioonilise läbinähtavuse tasemest. ${ }^{4}$ Mittearbitraarsed on nad aga selles

${ }^{3}$ Fraseologismidest kui märkidest on parömioloogilises uurimistöös kirjutatud siiski juba varem - seda on teinud rohkem vanasõnauurijana tuntud Grigori Permjakov 1960. aastatel (vt Permjakov 1968).

${ }^{4}$ Kui fraseologisme käsitleda ikooniliste märkidena, vastaks märgiteoreetiliselt sedalaadi motiveeritus Ferdinand de Saussure'i sekundaarsele motiveeritusele, vastandudes arbitraarsuse kui märgi motiveerimatuse mõistele (de Saussure 1966, 133). 
mõttes, et loogilised seosed kontseptuaalse sisendi ja väljundi vahel motiveerivad linke osaliselt leksikaalses struktuuris fikseeritud teadmistetasandi ja aktuaalse e kujundliku tähenduse vahel. See tähendab, et omades teadmist nii allika kui ka tähenduse kohta, võime ette kujutada, millised kognitiivsed protsessid viivad antud semantilise tulemuseni; see on põhjus, miks kujundlik üksus näib motiveeritavana. ${ }^{5}$

Nagu juba eespool märgitud, on fraseoloogia puhul ilmselge, et sugugi kõik fraseoloogilised üksused ei ole ühtmoodi motiveeritavad. Ent lisaks eristusele motiveeritus $v s$ mittemotiveeritus on võimalik eristada veel motiveerituse-sisest liigendust. Dobrovolski ja Piiraineni käsitluses on selleks motiveeritus vormi alusel ning motiveeritus tähenduse alusel ehk ikooniline ja sümboliline motiveeritus. ${ }^{6}$ Seejuures on tegu motivatsioonitüüpidega, mitte vastavate fraseologismide klassidega, st leidub fraseologisme, mis on motiveeritud niihästi vormiliselt kui ka semantiliselt $(1996,107)$. Parimateks näideteks selles osas on intensiivistavas funktsioonis võrdlused ja paarivormelid. ${ }^{7}$ Samuti on eelmainitud autorite sõnul ilmselge, et idiomaatilised väljendid kajastuvad mentaalses leksikonis tervikuna, kuna ilma eelteadmiseta, et nii võidakse midagi öelda, neid ei produtseeritaks. Seega ei ole tegu tähendusülekandega traditsioonilises tähenduses, vaid "teadmise-struktuuri operatsiooniga" (Operationen mit den Wissensstrukturen) (Dobrovolski, Piirainen 1996, 111). Siinkohal tuginevad nad oma seisukohtades nn lakofiaanlikele teoreetikutele: metafoorselt motiveeritud fraseologisme töödeldakse igapäevateadmiste, freimi/skripti/stsenaariumi teadmiste ehk mõistestruktuuri või muu kontseptuaalse struktuuri teadmise alusel. Idioomide aktuaalne tähendus tuleneb Dobrovolski ja Piiraineni käsitluses

${ }^{5}$ Seesugune arusaam langeb suuresti kokku kognitivistide eestkõneleja Georg Lakoffi väitega, et kuigi nn klassikalise lingvistilise käsitluse kohaselt on idioomidel arbitraarsed tähendused, eksisteerib kognitiivse lingvistika mõõdupuude järgi võimalus, et nad ei ole arbitraarsed, vaid pigem motiveeritavad, st nad tekivad küll automaatselt produktiivsete reeglite alusel, aga sobituvad kontseptuaalse süsteemi pakutavate mudelitega $(2007,275)$. ${ }^{6}$ Kuigi samad uurijad seadsid 1996. aastal endale eesmärgiks töötada välja kriteeriumid kahe motivatsioonitüübi eristamiseks, on nad üheksa aastat hiljem võtnud erinevate motivatsioonitüüpide interaktsiooni tähenduses kasutusele termini blending (Dobrovolski, Piirainen 2005, 103).

${ }^{7}$ Eesti keeles on vormiliseks motivaatoriks väga sageli algriim, seda just fraseoloogilistes võrdlustes ja sõnapaarides: täis nagu tarakan, saba ja sarvedega, lood ja laulud. 
freimist või skriptist e kognitiivsest struktuurist või assotsiatiivsest kontekstist teatud kindlate kontseptuaalsete operatsioonide tulemusena (2005, 164jj). Nimelt projitseeritakse lähtefreimide asjakohaseid teadmiste struktuure sihtfreimile ja tehakse sel moel võimalikuks vormi ja sisu ühenduse motiveeriv interpretatsioon. Seesuguse metakeelse tõlgendamise riistastiku eeliseks võrreldes traditsioonilise tähendusülekande mõistega peavad nimetatud uurijad võimalust käsitleda mitte ainult eksplitsiitseid, vaid ka idioomi kaudu n-ö esile kutsutud implitsiitseid elemente (siit ka eelmainitud nimetus "sisemine vorm"). Kujundlikkuse fenomen sisaldab komponentide semantilise autonoomia kõrval endas ka osutust fraseoloogilise tähenduse semantilisele jagatavusele, seetõttu ei ole võimalik analüüsida kujundlikkust ilma üksikute komponentide tähendusi fraseoloogilisse tähendusse haaramata. Dobrovolski ja Piirainen on seisukohal, et idioomi adekvaatseks semantiliseks kirjeldamiseks tuleb kaasata nn sisemise vormi ${ }^{8}$ olulised elemendid tähenduse selgitamiseks. Seegi asjaolu annab tunnistust fraseoloogilise üksuse motivatsiooni komplekssusest.

Samas ei ole need süvastruktuuri elemendid tingimata olulised järeldamiseks ja seega motivatsiooniks. Et tunnuste valik on vähem või rohkem suvaline, peab tuletusprotsessi nn ülesehitamine Dobrovolski ja Piiraineni arvates lähtumagi kontseptuaalsest struktuurist kui tervikust. Motivatsioonile vastavad töötlemisprotsessid võivad aga freimi (staatiline kontseptuaalne struktuur) või skriptiga (dünaamiline protseduuriline teadmisstruktuur) erineval määral seotud olla. Dobrovolski rõhutab ka oma ühistöös Anatoli Baranoviga, et kõik fraseologismid ei ole ühetaoliselt mõistetavad, st nende mõtestamine ei toimu ainult ühel tasandil, vaid fraseologismide seonduvaid mentaalseid kujundeid tuleb näha kolmel eri tasandil (Baranov, Dobrovolski 2008, 115):

- indiviidipõhised kvaasivisuaalsed ettekujutused,

- teadmiste tasand (s.o freimid, stsenaariumid, skriptid),

- kontseptuaal-metafoorne tasand.

Nende kahe uurija arvates on tänini fraseoloogide poolt peaaegu täiesti kõrvale jäetud just teisena nimetatu. Üheks põhjuseks pea-

${ }^{8}$ Terminiga "idioomi sisemine vorm" (inner form of the idiom) paralleelselt kasutavad samad autorid veel mõistet "kujundlik tähenduskomponent" (image component, bildliche Bedeutungskomponente / Bildkomponente / bildliche Komponente). Selle all peavad nad silmas nn mentaalset kujundit kognitiivses töötlemisprotsessis. 
vad nad asjaolu, et universaalsusele pürgivad mudeldamised ei võta üldse arvesse keeles sisalduvat kultuurilist spetsiifikat. Teisalt on piltlikud ettekujutused empiiriliselt paremini mõistetavad kui üldistatud kognitiivsed ehk kontseptuaalsed metafoorid.

\section{Piltlikkus või ikoonilisus?}

Motivatsiooni mõiste on tihedalt seotud idiomaatilisusega, viimane aga piltlikkusega ehk kujundlikkusega. Mida tuleks aga mõista piltlikkuse all? ${ }^{9}$

Fraseoloogia uurimises pikka aega juhtkohal olnud saksakeelses teadustöös (vt Burger 2003; Häcki Buhofer 1999) eristatakse kahte mõistet: üldisemas tähenduses kasutatav Bildlichkeit ehk piltlikkus ja kitsamas tähenduses Bildhaftigkeit ehk piltlikkus kui kujundlikkus/visuaalsus. ${ }^{10}$ Viimasena nimetatut tuleb mõista kui keelemärgi omadust ärgitada konkreetset kujutlus- e visualiseerimisvõimet. Kujundlikud on sellised sõnad ja väljendid, mida on võimalik hõlpsasti seostada konkreetse situatsiooniga, sest neil on tegelikkusega tajutav seos. Nii ongi osade idioomide puhul nii tema koosseisu kuuluvad sõnad kui ka väljendi enda otsene tähendus sedavõrd piltlikud (sks bildhaft), et kogu sündmus on ettekujutatav visuaalkonkreetsena. Tekkivaid kujundeid nimetavad näiteks Dobrovolski ja Baranov kvaasivisuaalseteks. Neist võidakse teatud olukordades, nagu näitavad samade uurijate tehtud eksperimendid, teadlikult n-ö tõukuda, ning need võivad, kuigi ei pruugi, olla seotud vastavate idioomide aktuaalsete tähendustega (Baranov, Dobrovolski 2008, 112). Samas võib assotsiatsioonidel põhinev tegevus isikuti ja kasutamisseoseti erineda.

Keelekujunditest on ikoonilisusega tugevalt seotud kahtlemata metafoorid, mis põhinevadki pildilisel alusel. Selline arusaam lähtub suuresti Juri Lotmanist, kes sedastas üheselt, et ikooni näol on tegu metafooriga $(1981,16)$. Seejuures pidas ta silmas ikooni kui

${ }^{9}$ Suurepärane näide vanasõnade ja kõnekäändude piltlikkusest on Pieter Bruegel seeniori maal "Netherlandish Proverbs" (1559), mille kohta on ilmunud mitmeid uurimusi (nt Dundes, Stibbe 1981). Vanasõnade ikonograafiast on mõned aastad tagasi detailsemalt kirjutanud Wolfgang Mieder (2008). ${ }^{10}$ Eesti keeles on paraku need mõisted raskesti eristatavad: EKSSi järgi on piltlikkus '(visuaalse) pildina esinev, selle kaudu toimuv; kujundirikas, kujundlik', visuaalsus 'kujundiline e kujundeid sisaldav või kasutav'. 
maalitud kujutist esmases ja otseses mõttes, mille sisu ja vormi vahel valitsevad aga keerukad mitteidentsussuhted.

Ikoonilisusest lähtuv käsitlusviis on fraseoloogia-uurimises alles viimastel aastatel taas enam tähelepanu leidnud, tavapäraselt on räägitud ikka fraseoloogilise üksuse kujundlikkusest/piltlikkusest. Ikoonilisuse-mõistega ${ }^{11}$ fraseoloogias on viimastel aastatel süvenenult tegelenud lisaks eelmainitud Dobrovolskile ja Piirainenile - küll mõneti teisest vaatenurgast - ka Ken Farø. Ka tema käsitleb ikoonilisuse-ilmingut motivatsiooni erijuhuna. Küll eristab Farø ikoonilisust ja ikonograafiat, eelistades viimast kui täpsemalt piiritletavat ja vähem subjektiivsemat fraseoloogias paljukasutatud piltlikkusele (2006, 62jj). Ikonograafiat määratleb ta idioomi potentsiaalina kutsuda kõnelejal idioomi otsese tõlgenduse alusel esile mentaalne kujutus. Ikonograafia ei ole Farø veendumuse kohaselt siiski sama, mis piltlikkus, mida traditsiooniliselt mõistetakse kui omadust tekitada visuaalset kujutluspilti - seega mitte psühholoogiline, vaid pigem keelemärgi nn semiootilis-psühholoogiline omadus (semiotisch-psychologische Eigenschaft) (Farø 2006). Kui ikonograafia puhul on tegemist mentaalse kujutusega, mis tekib idioomi sõnasõnalise e otsese mõistmise alusel, siis ikoonilisusega on tegu juhul, kui idioom n-ö peegeldab vormi kaudu oma sisu. Kuigi Farø arusaama kohaselt on fraseologismid ikoonilised, sest nad n-ö peegeldavad oma sisu - st kujutavad seda, mis on seotud sisuga, ning seega on semantiliselt läbipaistvad keelekasutajatele, kes nende tähendust juba tunnevad - leiab ta, et "tegemist on väga jämedateralise kujutusega" (groß granulierten Abbildung) (Farø 2006, 63). Nagu Dobrovolski ja Piirainen, sedastab ka Farø, et sisu, mis n-ö läbipaistvaks tehakse, moodustab vaid väikese osa idioomi aktuaalsest tähendusest, st mitte mingil juhul ei saa ka ikoonilisuse puhul rääkida sisu ja vormi üksühesusest. Seega ei tähenda ikoonilisus suhet kõigi vormi- ja sisuelementide vahel põhjusel, et tegemist on vaid väikese osaga nn tegelikust sisust, st idioomi kõikidest kasutusomadustest.

\footnotetext{
${ }^{11}$ Eesti lingvistikast leiab ikoonilisuse määratluse Helle Metslangilt (1993, 204): "Ikoonilisus on läbinähtavuse avaldus, nähtus, mis seisneb selles, et vorm peegeldab mingis mõttes sisu. Ikoonilisus on küll keelte arenedes ja nende abstraktsuse kasvades pidanud tublisti taanduma arbitraarsuse ees, kuid on siiski küllalt mõjukas, hõlbustades informatsiooni vastuvõtmist, töötlemist ja edastamist."
} 
Dobrovolski, kes on kõige enam tegelenud motivatsiooni mõiste määratlemisega, peab semantilise mitmetähenduslikkuse või motivatsiooni samastamist piltlikkusega veaks $(1997,47)$. Semantilise mitmetähenduslikkuse (semantic ambiguity) alusel idioomide suhestamine motivatsiooniga ei ole paljudel juhtudel sugugi üheselt selge. Idioom võib koosneda semantiliselt sobimatutest sõnakombinatsioonidest (ill-formed strings), omada üksnes kujundlikku tähendust ning olla ikkagi motiveeritav. Seega ei ole piltlikkuse eelduseks semantiline mitmetähenduslikkus, sest on olemas ka sõnasõnalise tähenduseta idioomid, mille nn piltlik sisu on absurdne. Ehk, nagu toonitab Dobrovolski, on idioomid sisuldasa sagedasti reaalses maailmas võimatud ja absurdsed, see on tavaloogika rikkumine: sõnakomponendid, mis vormiliselt seostuvad kehtivate süntaktiliste mudelite alusel, ei moodusta maailmapildiga haakuvat tähendust. Nii ongi tulemuseks naljakad assotsiatsioonid. Nagu rõhutavad Baranov ja Dobrovolski, ei ole sellisel juhul aga abi visualiseerimisest, vaid toetutakse teadmusele, milles on oluline roll kognitiivsusel $(2008,112-113) .{ }^{12}$ Nad tõdevad, et vaatamata eelmainitud kvaasivisuaalsetele ettekujutustele on iga motiveeritud idioomi "külge kinnistunud" kindel tähendus, mis tuleneb sobivast kontseptuaalsest struktuurist, freimist või stsenaariumist ega ole teadlikult registreeritav. Sama postuleeris Dobrovolski ka koos Piiraineniga tehtud uurimistöö tulemusena, nagu eespool osutasin.

Kokkuvõtvalt võib nentida, et leidub erinevaid arusaamu nn sisemise pildi (e kujundliku tähenduskomponendi) osatähtsusest tunnetusprotsessis, aga lähtuda võiks sellest, et visuaalsed ettekujutused pakuvad kontseptsioonidele vähemalt sama head kui mitte paremat ligipääsu kui mõisted. On selge, et fraseologismid võivad pakkuda ka visuaalseid kujutluspilte, mis ühelt poolt mõistet konkretiseerivad, kuid teisalt toovad sisse täiendavaid tähenduselemente, millel ei ole väljendi tähendusega mingit pistmist.

${ }^{12}$ Sama mõistekompleksiga on tegelenud ka kognitivistid, kelle üheks märksõnaks oli üldisem kehastumine (embodiment), mitte kitsalt vaid visualiseerimine. Nii kohaldab Mark Johnson oma raamatus "The Body in the Mind" (1987) füüsilise maailma kogemise kohta mõistet "geštalt", mille kohaselt on kogemused struktureeritud juba keele-eelsel füüsilisel tasandil. 


\section{Visualiseerimisest motivatsiooni hõlbustajana psühholingvistilisest aspektist}

Eeltoodu esindas lingvistide-fraseoloogide arusaamu motivatsioonist ja selle rollist fraseoloogiliste väljendite mõistmises. Teisalt on kujundlikkuse mõistmisega ja visualiseerimise rolliga selles tegelnud aktiivselt ka psühholingvistid, keskendudes idioomidele.

Olulisimaks uurijaks on selles vallas olnud pikka aega Raymond W. Gibbs Jr., kelle psühholingvistilistel katsetel põhinevad uurimused osutavad, tsiteerides Dirk Geeraertsi, "et idioomi motiveerivad kujundid on psühholoogiliselt tõelised (motivating image for idioms are psychologically real) (2002, 452). Kui algsed seosed kaovad, siis motivatsioon küll kannatab selle tagajärjel, ent samas võivad esiplaanile kerkida teised seosed ning väljend võib ikkagi omandada motivatsiooni. Samas aga ilmnevat seegi, et suurema motivatsiooni otsimine toob kaasa tõlgenduse muutumise. Olulisim tõdemus, mida sama uurija on idioome käsitledes sedastanud, seisneb selles, et mõtestamisprotsessis ei läbita vaheastet, milleks on otsene tähendus, vaid otsustatakse kohe kujundliku tähenduse kasuks; sellist mudelit tavatses ta nimetada direct access model/view/ hypothesis (Gibbs 1994). See mudel põhineb arusaamal, et väljendid koos tähendustega on ladustatud mentaalsesse leksikoni ning on alati saadaval esimestena. Gibbs, kelle arvates ei ole mingit põhjust pidada otsest tähendust psühholoogiliselt primaarseks, st millekski, mis eelneb töötlemise käigus alati järgmistele etappidele $(1989,249)$, on toonitanud, et tegemist on lihtsalt keelelise mõistmisprotsessi erisuguste tulemustega - see on nn psühholoogiline tegelikkus (psychological reality). Metafoori kasutatakse edastamaks erinevaid ebamääraseid, mitteotseseid tähendusi, mille taastamist piirab tugevasti kontekst, mida kõneleja ja kuulaja jagavad. Inimeste intuitsioonid idioomide taga seisvate mentaalsete kujundite kohta on Gibbsi arvates idioomide kujundlikku tähendust motiveerivate spetsiifiliste kontseptuaalsete metafooride kaasprodukt. Kuigi reaalselt ollakse idioomi puhul vastamisi kahte tüüpi tähendusega - otsese ja kujundlikuga -, motiveerib idioomi kujundit ja põhjustab selle automaatset aktiveerimist just kontseptuaalne metafoor. Sellise käsitlusviisi kohaselt võimaldab automatism mööda minna konkreetsest otsetähendusest.

Mõneti on Gibbsile üritatud ka oponeerida. Cristina Cacciari ja Samuel Glucksberg märgivad, et mõtestamine komplitseerub just 
seesuguste idioomide puhul, mis märgivad ka otseses tähenduses täiesti mõeldavaid konkreetseid tegevusi, mis võivad, ent ei tarvitse olla semantiliselt seotud idioomi kujundliku tähendusega (Cacciari, Glucksberg 1995, 46). Sellisel juhul võib nende meelest väga tõenäoliselt tekkida visuaalne kujund, mis peegeldab pigem otsest kui idiomaatilist tähendust (või siis assotsieerub pigem nn otsetähendusliku stseeniga, mis suuresti sõltub sellest, kui automaatne on vastava idioomi mõistmine). Idioomide mõistmist ja kasutamist ei saa aga Cacciari ja Glucksbergi arvates käsitleda pelgalt sõnatähenduste aktiveerimisena, vaid tuleb arvestada ka kreatiivsusega, st neid kasutatakse sobiva konteksti korral. Kui idioomide puhul on võimalikud mitmed tõlgendused, valitakse kontekstuaalse ja situatiivse info abil välja sobiv, nii et selles mõttes on võimalik ühene interpretatsioon.

Gibbs aga ei ole nõus väitega, mille kohaselt põhinevat tavakõnelejate mentaalsed kujutused idioomide kohta lihtsalt idioomi kujundlikul tähendusel või koguni nende idioomide aluseks olevatel kontseptuaalsetel metafooridel. Sarnaselt Cacciari ja Glucksbergi korraldatud katsetele osutavad ka Gibbsi eksperimendid ilmekalt, et esmalt moodustavad inimesed mingi idioomi kohta väga konkreetse, otseses tähenduses mõistetava kujundi. Erinevate idioomide mentaalsed kujundid on aga omavahel kooskõlas, see terviklikkus ei põhine Gibbsi arvates sarnasel kujundlikul tähendusel, vaid sellel, et iga idioomi motivatsiooni tagab sarnane kontseptuaalne metafoor. Gibbs resümeeris koos Nandini Nayakiga oma katsete tulemusena (Nayak, Gibbs 1990, 322), et inimesed on mitte üksnes võimelised tuvastama idioomide vahelist metafoorset sarnasust, vaid nad kasutavad seda teadmust ka siis, kui on vaja otsustada idioomide sobivuse üle teatud kontekstidesse - idioomi ja teda ümbritseva konteksti kontseptuaalne koherentsus mõjutab otseselt idioomist arusaamise kiirust. Testid osutavad, et kontseptuaalsed metafoorid mõjutavad küll inimeste otsustusi idioomi sobivuse kohta erinevates kontekstides, ent ei ole kättesaadavad idioomi online mõistmisel. Isegi kui katseisikutelt sooviti metafoori kujundlikku parafraasi, anti vastusena ikkagi enamasti selline, mis oli vasturääkivuses seonduva kontseptuaalse metafooriga. Gibbs rõhutab $(1998,105)$ aga, et tema ega ta kolleegide seisukohtadest ei järeldu, nagu poleks kontseptuaalsed metafoorid idioomi mõistmisprotsessis kohe kättesaadavad, st kui osalejad ei ole veel kujundlike fraaside tõlgendamisega lõpule jõudnud, vaid seda tõlgendamist tuleks interpreteerida 
üksnes vihjena, et kontseptuaalsed metafoorid aktiveeritakse kas samaaegselt või kohe pärast seda, kui ollakse idioomist aru saanud.

Loomulikult pääseb idioomi mõtestamisel kontseptuaalsetele metafooridele tunduvalt hõlpsamini ligi kui juhusliku keelelise metafooriga kokku puutudes, seda tavapäraseks muutunud tiheda seose tõttu idioomi ja kontseptuaalse metafoori vahel. Liiati on enamik kontseptuaalseid metafoore andnud erinevaid idiomaatilisi/konventsionaalseid väljendeid, st kontseptuaalsed metafoorid on aluseks kognitiivsetele protsessidele, mille käigus kujundkõnet tõlgendatakse (Gibbs 1998, 106-107): teatud idioomide sagedasem kasutamine ja neile kontseptuaalsete metafooride kaudu motiveeringu omistamine võib muuta kontseptuaalsed metafoorid esilekerkivamaks ja kättesaadavamaks situatsioonis, kus idioome kuuldakse või loetakse. ${ }^{13}$ Gibbs toonitab talle omaselt, et millegi esmaseks-teiseseks pidamine ei tähenda tingimata erinevaid kognitiivseid protsesse, pigem on küsimus esilduvuses. Asjaolu, et inimesed analüüsivad automaatselt väljendi koosseisu kuuluvate sõnade otseseid tähendusi, vajaks Gibbsi meelest veel täpsemat uurimist. Selle raames tuleks tema arvates eelkõige loobuda otsesuse (literalness) mõistmisest lingvistilises tähenduses.

Kümme aastat hiljem on Gibbs oma seisukohti ümber hinnanud, väites, et tema 1998. aastal püstitatud kontseptuaalse mõistestamisega seotud hüpoteesid olid kantud ideest käsitleda metafoorsete mudelite ning keelekasutuse ja -mõistmise erinevate aspektide interaktsiooni hierarhilisena. Selle teadmuse põhjal leiab ta koos Markus Tendahliga avaldatud uurimuses mõttekama olevat lähtuda keelemõistmise tõlgendamisel kontseptuaalse metafooriteooria asemel hoopiski kontseptuaalse segunemise mõistest (blend) (Tendahl, Gibbs 2008, 1843).

Mentaalsete kujundite osatähtust kujundkeele mõistmises ja töötlemises on viimastel aastatel üritatud jätkuvalt välja selgitada. Selleks on korraldatud arvukalt teste eelkõige katseisikute seas, kes mingi teise keele valdajana õpivad süvendatult inglise keelt. Kuigi metoodika pädevate järelmite tegemiseks on alles arene-

\footnotetext{
${ }^{13}$ Siia kõrvale sobib tuua Rachel Giora väljatöötatud astmelise esilekerkivuse hüpotees (Graded Salience hypothesis). Selle kohaselt mõjutavad sõna esilduvust mentaalses leksikonis konventsionaalsus, sagedus, tuttavlikkus ja prototüüpsus/stereotüüpsus (Giora 2003, 15). Seega on selline leksikon avatud ka muutustele. Kontekstuaalseid mõjureid hindab Giora suhteliselt madalaks.
} 
misjärgus, näitavad need üheselt, et kujundite mõtestamine on suuresti individuaalne. Samas näitavad eksperimentide tulemused, et visualiseerimine hõlbustab täiesti tundmatu idioomi tõlgendamist paremini kui sõnasõnaline kirjeldus (vt Boers et al 2009), mis võib, aga ei pruugi, mõtestamisele kaasa aidata. Kognitiivseid pingutusi mõjutab ka etümoloogilise selgituse esitamine. Opaaksete idioomide puhul võib sellest tulu tõusta, aga ei pruugi (Boers et al 2009; Szczepaniak, Lew 2011). Lisaks võidakse teisiti tõlgendada koguni idioomi koostisse kuuluvaid ühetähenduslikke sõnu või ei suudeta määratleda üheselt idiomaatilise väljendi allikdomeenilist kuuluvust. Siinkirjutaja kogemus fraseoloogia küsitluse osas viitas küll vastupidisele: tundmatu väljendi tõlgendamisel tuginetakse assotsiatiivsetele seostele ning tulemina antud selgitus on vähem või rohkem seotud väljendi nn aktuaalse tähendusega (Baran 2008). Samas oli tegu emakeelsete kõnelejatega, kellel on toetuspunkte rohkem kui keele mittevaldajatel. On ilmne, et kujundliku keele mõistmiseks ei piisa üksnes teise keele ükskõik kui heast valdamisest. Sõnad, millel on püsiväljendis nn seotud tähendus, võivad kontekstivabas kasutuses olla mitmetähenduslikud - asjaolu, mis muudab fraseoloogilise kujundi mõtestamise mitte-emakeelsele kõnelejale keeruliseks. Osa uurijaid tavatseb rääkida sellega seoses koguni erilaadsest fraseoloogilisest metafoorist (vt Naciscione 2010). Siinkirjutajale näib see siiski ebavajaliku eritlemisena.

Keele mõistmine, mida metafoori kui keskse kujundi tuvastamise mudelid hõlbustavad, eeldab ka kultuurilise konteksti adumist. Selle-alase vajakajäämise korral võib fraseoloogilise kujundi mõtestamisel olla abi kujundi visualiseerimisest kui vihjest. Iseäranis kohtab seda tänapäeval reklaaminduses, mis avaliku ruumi komponendina on meie elus kesksel kohal tahes või tahtmata. Lisaks tavapärastele esinemiskohtadele (avalik linnaruum, trükimeedia, televisioon, raadio) kasutab reklaamitööstus üha enam internetikeskkonda, ilmutades paindlikkust sellega, et kasutatakse varmalt ära erinevaid multimeedia vahendeid. Visualiseerimine kui reklaami keskne element, toimib viitena sidususele, mis võimaldab mõtestamist/mõistmist sellal, kui pelk tekst jääb arusaamatuks või on n-ö möödalugemise objektiks. Ehk nagu on pildilisuse ja kujundlikkuse vahekorra uurija Charles Forceville $(1994,6)$ toonud välja reklaamide puhul, hõlbustab visuaalne kontekstualiseerimine verbaalse metafoori mõistmist. 
Alljärgnevad näited esindavad teksti ja pildi kombinatsiooni. ${ }^{14}$ Pilt toimib omamoodi mnemoonilise e mõistmist hõlbustava abivahendina - esitatud väljend kontekstualiseeritakse. Samuti võidakse loomulikult pildiga n-ö manipuleerida. Seal võidakse mõnda aspekti esile tuua ja mööda minna teistest peaaegu samaväärsetest, mida lihtsalt ei peeta oluliseks või ei taheta sihilikult välja tuua. Kuigi mõistestamist suunatakse teadlikult (või vähemalt üritatakse seda teha), on vastuvõtt suuresti kognitiivne, st tähenduste konstrueerimine on individuaalne. Nagu on ilmnenud katsetest, on täielik konsensus tähenduste osas äärmiselt harukordne (Szczepaniak, Lew 2011). On ilmnenud seegi, et kognitiivse ökonoomia eesmärgil pakutakse nn lahendusena esimesena mälus esiletulevat. Pikka aega on lähtutud teesist, et fraseologismide mõistestamisel tehakse ebatüüpilist laadi (nn fraseoloogia-spetsiifilisi) kognitiivseid pingutusi. Samas on see arusaam vastuolus fraseologismidele omase reprodutseeritavusega, mis on kahtlemata kognitiivse kulutuse ökonoomsemaks muutmise teenistuses (Häcki Buhofer 1999). Lahendusena on psühholingvistid soovitanud vaadelda idioomi omandamist osana laiemast nähtusest - selle all peetakse silmas üldisi kognitiivseid mehhanisme, mis on semantilise pädevuse ja keelelise arusaamise aluseks (Levorato, Cacciari 1999, 54).

\section{Fraseologismide visualiseerimine reklaamides}

Massimeedia ühest ilmingust nimega reklaam on kindlalt saanud tänapäeva kultuuri osa. Selle mõjud näivad kõige tugevamad olevat noortekultuuris, mida näitas ilmekalt ka koolipärimuse kogumise võistlus aastal 2007..$^{15}$

Reklaam on saanud avaliku ruumi osaks, selle edastamiseks kasutatakse erinevaid meediakanaleid (sh internetti) ja seda kohtab tänavapildis. Informeerimise asemel on reklaami eesmärgiks üha sagedamini mõjutamine. Nüüdisaegne reklaam on kõikjal, st sama

\footnotetext{
${ }^{14}$ Iseküsimus, kuivõrd saab tänapäeval rääkida järsust teksti ja pildi eristamisest. Internetikeele uurija David Crystal (2001) on võrrelnud internetikeskkonna kirjutustava animeeritud keelega.

${ }^{15}$ Kogumisvõistluse korraldas Eesti Kirjandusmuuseumi folkloristika osakond koos Eesti Rahvaluule Arhiiviga. Eelmine selline suurem aktsioon toimus 15 aastat varem.
} 
sõnumi edastamiseks kasutatakse korraga erinevaid kanaleid, mis tagab ulatuslikuma mõju. Kõikjal esinemise tõttu on reklaamist saanud oluline kommunikatsiooniilming.

Üks reklaamivõtteid on huumorit, sõnamängu jm ootamatust taotlevad reklaamid ehk efektile toetuvad tekstid. ${ }^{16}$ Tekstilise osa kõrval on reklaami üheks põhielemendiks pilt. Selle funktsioon on ilmestada reklaamiteates sisalduvat lugu, ja see peab seostuma reklaami põhiideega. Ehk nagu on toonud esile reklaamipsühholoogia, kui üks visuaalreklaami vastuvõtmisel toimuvast tegevusest - pildivaatamine, juhtlause lugemine, põhiteksti lugemine - peaks ebaõnnestuma, on reklaam läbikukkunud (Bachmann 2005, 55). Seega on psühholoogilise mõju (reklaami eesmärgi) saavutamiseks ühtmoodi olulised kõik komponendid.

Kuigi järgnevad enamjaolt trükireklaami esindavad näited on valitud pigem soovist näidata fraseologismi eesmärgipärase visualiseerimise võimalikkust hoolimata kujundi kahetisusest (või just tänu sellele), on need ühtlasi ilmekad tunnistajad visuaalsuse üha suuremast olulisusest. Küsitluste põhjal näivad noorte tähelepanu osaliseks saavat eelkõige animeeritud, multimodaalsed reklaamid, mitte niivõrd pelgad staatilised trüki- või välireklaamid. ${ }^{17}$ Kuigi alati leidub ka erandeid, on reklaamide puhul olulisim teksti ümbritsev visuaalsus. Nagu on osutanud ka reklaamiuuringud, eelistavad inimesed reklaami, milles $70-80 \%$ hõlmab visuaalia (Bachmann $2005,67)$. Seega jääb verbaalse osa kanda kõige rohkem $30 \%$ reklaami kogupinnast.

On mõistetav, et tänapäeva ühiskonnas, kus kirjalikkus on muutunud domineerivaks, püütakse teksti ilmtingimata ilmestada võimalikult mõjusa visualiseerimisega. Ekspressiivse fraseoloogilise väljendi kasutamine reklaamides annab selleks väidetavalt parima võimaluse, kuna see toimivat pilgupüüdja-tähelepanuäratajana põhjuseks värvikus ja teatav tuttavlikkus (Röhrich 1978, 87; Fiedler 2010,6). Seega omistatakse kujundlikele püsiväljenditele omadusi, mis on uuemate uuringute valguses üpris suhtelised. Seda tähelepanuväärsem on aga asjaolu, et ka praktikud ehk antud juhul reklaamitegijad ei pelga sõnumit edastada seesugustegi väljendite

16 Termin pärineb Talis Bachmannilt ja tähistab tekste, mille meelelahutuslik osakaal võrreldes teiste alaliikidega on suurim (Bachmann 2005, 60). ${ }^{17}$ Multimodaalsuse aspektist fraseologisme kasutavates reklaamides on kirjutanud lähemalt fraseoloog Erla Hallsteindóttir (2011). 
kaudu, mis võivad tänapäeval olla oma aktuaalsuse ja motivatsiooni koguni minetanud.

Reklaame uurides ilmneb, et reklaamitegijad keskenduvad teatud kindale sihtrühmale. Samas ei saa nad välistada ülejäänuid, nn rühmast väljapoole jäetuid, kes kuuluvad ju tarbijatena samasse avalikku ruumi. Seega on meil kõigil nn vastuvõtjatena võimalus tõlgendada neid sõnumeid, mida tegijad ise on juba eelnevalt loovalt tõlgendanud. Toimub omamoodi topelttõlgendamine, sest korra juba kellegi poolt teistlaadse sisu omandanut on võimalik uuesti mõtestada ja mitte tingimata samas suunas. Sellega võib kaasneda näiteks ekspressiivsuse ja koomilise mõju süvendamine. Nii mõneski mõttes sarnaneb see huumoriteoreetikute poolt väljapakutud ühildamatuse lahendamisele (vt Krikmann 2004, 130jj): nn prototüüpsest kasutusest erinev tõlgendus (e mitteprototüüpne kasutus) loob võimaluse omakorda uuteks markeeritud tõlgendusteks ja nendest tulenevateks mõjudeks. Reklaamides omandavad seesugused eesmärgistatud modifikatsioonid erinevatel tasanditel (semantilisel, funktsionaalsel) lisatähendusi. Selliste nn hälbimiste mõistmine eeldab aga iseäranis nende ebapiisavas keelelises kontekstis kasutamise tõttu teatavat kompetentsi. ${ }^{18}$ Üldiselt peetakse piltide kommunikatiivsust universaalsemaks kui verbaalset keelt, ent lähemal uurimisel kipub ilmnema, et ka piltidele omistatav universaalne arusaadavus toimib kultuurikonteksti piires (Laaniste 2005, 618; Hallsteindóttir 2011). On selge, et nii kujundlikku keelekasutust kui ka visuaalset keelt seostavate piltkujutiste mõistmiseks ei piisa üksnes teise keele kui sellise ükskõik kui heast valdamisest. Asjaolu, millest need, kes tähendusi loovad, et saavutada mingeid eesmärke, ei näi alati olevat teadlikud. ${ }^{19}$ Siinkohal võib vaid nõustuda Peeter Toropi nendinguga verbaalse ja visuaalse komplitseeritud seose kohta, et "teksti ja kujutise vahekord on keskne meediaanalüütiline probleem, mis ühtlasi on ka kultuuri enesekirjelduse ja enesemõistmise oluline probleem" (Torop 2008, 731).

${ }^{18}$ Kuigi huumori sihipärasel kasutamisel reklaamis on uuringute järgi positiivse emotsiooni tekitamise efekt, võidakse kergesti libastuda, mistõttu seda soovitatakse rakendada üksnes kitsendatud tingimustel (Bachmann 2005, 98-99).

${ }^{19}$ Reklaami tajumisega seonduvast, $k . a$ visuaalse taju eripärast reklaamis, vt Bachmann 2005. 
Järgnevalt analüüsin mõningaid fraseologismide visualiseerimise ning teksti ja pildi vahekorra näiteid kodumaistes reklaamides. ${ }^{20}$

Reklaamides kasutavaid fraseologisme muudetakse tihtipeale nii vormiliselt kui ka sisuliselt. Tekkivate modifikatsioonidega seoses on räägitud ka mõistest nimega remotivatsioon (Varga 2010). Tegemist on terminiga, mida näiteks Burger soovitab aga vältida kui ebatäpset: selle sisu ei ole mitte nn geneetilise protsessi ümberpööramine, vaid fraseologismi võimaliku sõnasõnalise teisendi või tema koosseisu kuuluvate ühe või mitme komponendi mingite aspektide aktiveerimine (Burger 2003, 68). Remotivatsiooni asemel võiks tema arvates rääkida ikkagi toimunud muutustest olenevalt kas teistlaadsest motiveeringust või sõnasõnalise variandi aktualiseerimisest. Ka käesolevas artiklis on lähtutud just seesugusest arusaamast.

Esimeses reklaaminäites (foto 1) on sõnumi edastamiseks kaasatud ühelt poolt tuntud püsiväljend, teisalt aga sümbolid ja stereotüübid. Tekstina on kasutatud traditsioonilist kujundlikku püsiväljendit silme ees läks mustaks (Kui leivaisu võtab silme eest mustaks). Seda on mõnevõrra muudetud: minema asemel on kasutatud hoopis verbi võtma, tähenduses 'seisundit esile kutsuma'. ${ }^{21}$ Varaseim üleskirjutus eesti kõnekäändude ja fraseologismide andmebaasis pärineb aastast 1937: Keik ilm lää silmade ees mustaks. Tegelik tuntus ulatub siiski kaugemasse aega, sest juba 1840. aastal kasutas seda oma jutus "Viina katk" Friedrich Reinhold Kreutzwald:

Juhtus ükskord emmaga, kes nisammoti jowastano olli, rängaste rido; emma söimas ja torrises ni kaua wasto, kunni issa irmsal kombel needma ja wanduma akkas, et minno ihhokarwad püsti töusid ja köik mul silmade ees mustaks läks. ${ }^{22}$

Toetudes allikandmetele võib üpris kindlalt pidada seda väljendit saksa laenuks jem. wird es schwarz vor den Augen (Röhrich 1973), mis on eesti keeles leidnud kindla koha ja olnud kasutuses juba

${ }^{20}$ Peaaegu kõiki vaadeldavaid reklaame on ära märkinud Eesti Reklaamiagentuuride Liit Kuldmuna-nimelise auhinnaga.

${ }^{21}$ Reklaamikeeles kasutavatest keelevahenditest, sh verbivormide esinemusest, lausestruktuurist, aga ka tekstuaalsetest tunnustest on kirjutanud lähemalt Reet Kasik (2000).

${ }^{22}$ Antud näide pärineb vana kirjakeele korpusest Vakkur. Huvitaval kombel sisaldub varasema leksikograafia olulisimas teoses, Ferdinand Johann Wiedemanni eesti-saksa sõnaraamatus (esimene trükk 1869) pelk väljendverb mustaks lööma ilma selgitava näitelauseta. 


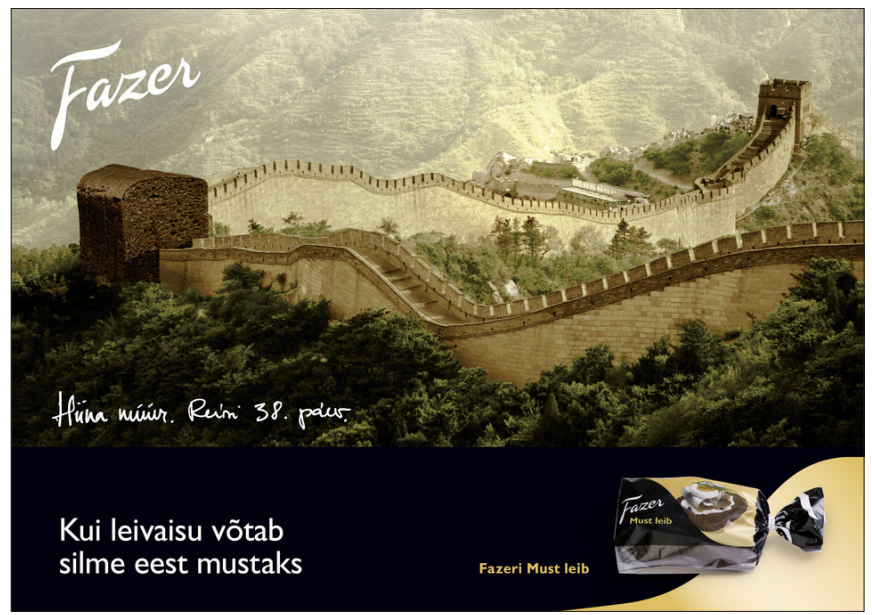

Foto 1. Fazeri reklaam.

sajandeid. Tegelikult on antud reklaaminäite puhul esmapilgul peaaegu võimatu näha teksti ja kujutatu seost. Reklaamisarjas on kõrvutatud eesti traditsioonilist leivatoodet maailmakuulsate silmapaistvate rajatistega (lisaks Hiina müürile veel Stonehenge Inglismaal). Tegijaid on tõenäoliselt mõjustanud stiimulsõnana toimiv lekseem must: must leib > silme eest läks mustaks. Tuleb üksnes tunnustada autorite oskust mängida nii verbaalsel kui ka visuaalsel tasemel ning sealjuures ka kultuurisümbolitega: eestlastele olulist musta leiba on kõrvutatud ülemaailmselt tuntud sümbolitega. Ühtlasi on tegu humoorika naljaheitmisega stereotüüpse mõtlemise üle: kui eestlane on võõrsil reisimisest väsinud, nähakse vaimusilmas kõikjal vaid ühte. Seda väljendas ka telereklaam, milles kodumaale naasnud tütarlaps jookseb lennujaamast kohe poodi musta leiva järele, sest see on midagi, millest ta mujal viibides puudust on tundnud:

Kõige teravam musta leiva isu on alati pikalt reisilt tulles. Võiks isegi mü̈̈a komplektina: must leib, hapukoor ja heeringas. See on toit, mis annab selle õige koju jõudmise tunde. Eestlastest on nü̈̈d juba suur enamus välismaal viibinud ja see tunne on paljudele vägagi tuttav. Onnitlen tegijaid hea reklaami puhul! Usun, et see reklaam kaevub sügavale musta leiva rahva südamesse. (Henri Jääger 2008) 
Ka tootja enda, kes on hoopis Soome päritolu, kodulehelt leiab samasugust retoorikat sisaldava tootetutvustuse:

Palju on räägitud võõrsil olles tekkivast igatsusest Eesti musta leiva järele. See pole lihtsalt leib, mida ollakse harjutud sööma. See on tõeline kodutoidu sümbol, mida igatsetakse Eestist eemal olles kõige enam. (Fazer 2012)

Kuigi teatav klišeelisus on osa nii reklaami kui ka traditsioonilise väljendi olemusest, võidakse mõlemale loominguliselt lähenedes saavutada märksa mõjusam tulemus. Nagu eeltoodud näitest ilmnes, on võimalik visuaalselt ühitada tootereklaam ning kultuuritraditsioonid ja sümbolid. Sama sümboolikat on oma leivatoodete puhul kasutanud teisedki Eesti leivatootjad. Samas on selge, et kultuurilist konteksti hoomamata jääb reklaami sõnum üsna tõenäoliselt arusaamatuks. ${ }^{23}$

Teise näite puhul (foto 2) on tegemist pangandusreklaamiga, mille sõnum on lihtne: meie oleme teistest paremad (Puust ja punaselt: Sampo teeb kõige parema kodulaenu pakkumise). Reklaam rajaneb tuntud väljendi tee puust ette ja värvi punaseks (varaseimad üleskirjutused EKFAs 1960. aastatest: tee või puust ette; tekstid lisandusega värvi punaseks pärinevad paarkümmend aastat hilisemast ajast) sõnasõnalise ehk leksikaalse sisu visualiseerimisel: pintsel ja maalrivärv on need atribuudid, mis seostuvad otseselt värvimisega. Kujutis pintslit hoogsalt (kujutatavat puidust pinda mööda) liigutavast käest väljendab lisaks protsessi, st midagi sünnib just nüüd ja praegu. Tõenäoliselt on visualiseerimisega taotletud lisamõjugi: punane kui intensiivne, kahtlemata pilkupüüdev värv. Kuigi punane on sümbolina üldiselt universaalne, on sellele värvile omane ka teatav ambivalentsus: eri kultuurides on tal nii positiivseid kui ka negatiivseid kõrvaltähendusi. ${ }^{24}$ Nii eesti kui ka soome traditsioonis on punasel ajalooliselt positiivne roll (Sarapik 1998, 23-25), kuid just Eestis on sellele värvile lisandunud postsotsialistlikule ühiskonnale omaselt ka negatiivseid varjundeid. Seega on kõiki tähendusi arvestamata võimalik visuaalse sõnumi hoopis teistsugune, st mitteoodatav mõju.

${ }^{23}$ Täiesti teistsugused on suurte üleilmsete firmade reklaamid, mis üritavad oma toodet müüa ühesuguse sõnumiga kõikjal või seda üksnes mõnevõrra oludele vastavaks mugandades (vt Leičik 2006).

${ }^{24}$ Nimetuse "punane" kasutamisest erinevate keelte fraseoloogias on kirjutanud Dobrovolski ja Piirainen (1996, 265-267). 


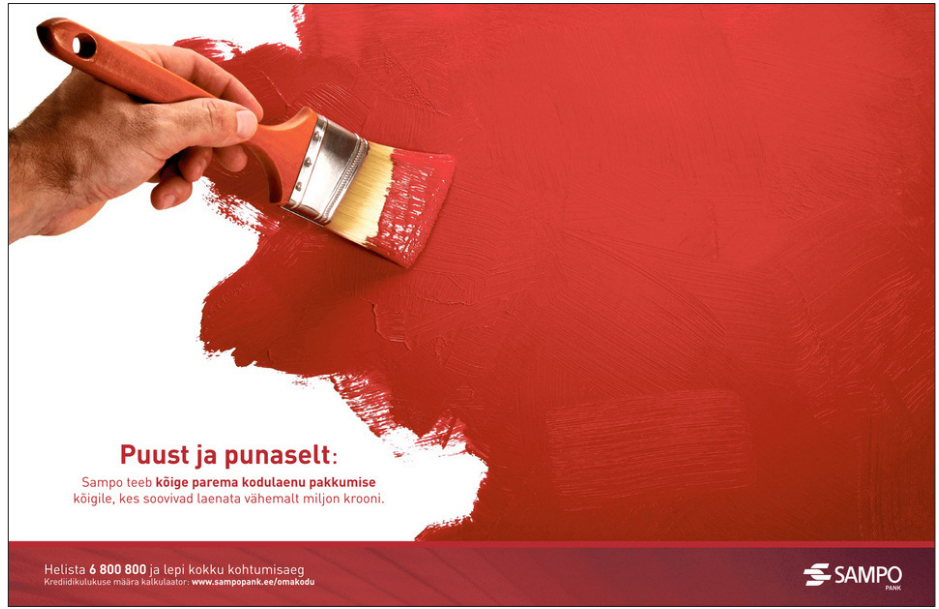

Foto 2. Sampo kodulaenu reklaam.

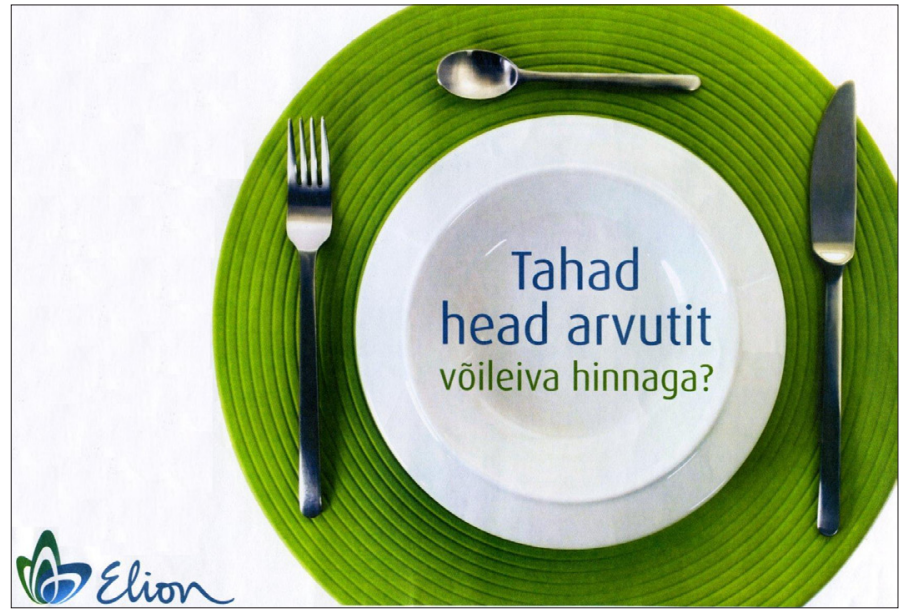

Foto 3. Elioni sooduskampaania reklaam. 
Nagu eelmises näites, on siingi tegemist välismaise firmaga - asjaolu, mis on omane peaaegu kõigile siintoodud reklaaminäidetele -, kes on kasutanud tootereklaamis eesti traditsioonilisi püsiväljendeid ning üritanud neid visuaalselt ilmestada.

Kolmandaski reklaaminäites (foto 3) on kasutatud eesti keeles hästituntud väljendit (Tahad head arvutit võileiva hinnaga?). Vähendavas tähenduses liialdava adverbifraasi võileivahinna eest tähenduseks on 'üliodav, imeväikse hinna eest, poolmuidu'. Seda, et tegu on vana väljendiga, osutavad ka tekstid eesti kõnekäändude ja fraseologismide andmebaasis, varaseimad neist pärinevad 19. sajandi lõpust (1889). Küll on nendes sõnastus veidi teistsugune - võileiva eest (nt Andis võileiva iest ära.). Alles 1940. aastatest võib kohata väljendi kasutust leksikaalse komponendiga 'hind'. Ka seda väljendit söandan päritolult pidada pigem algselt tõlkelaenuks saksa keelest: etw. für ein Butterbrot hingegeben (Röhrich 1973).

Reklaamis sisalduv nappe vahendeid kasutav visualisatsioon evib vaid kaudseid vihjeid väljendi leksikaalsele sisule (söögiriistad lauale asetatuna), mitte otsest kujutamist. Kuigi reklaamis kasutatud objektidel on fraseologismi bukvaalse tähendusega üpris ebamäärane seos, on sõnum tänu ütluse laiemale tuntusele tõenäoliselt siiski hõlpsalt mõistetav. Iseasi, kuivõrd kehtib reklaamis

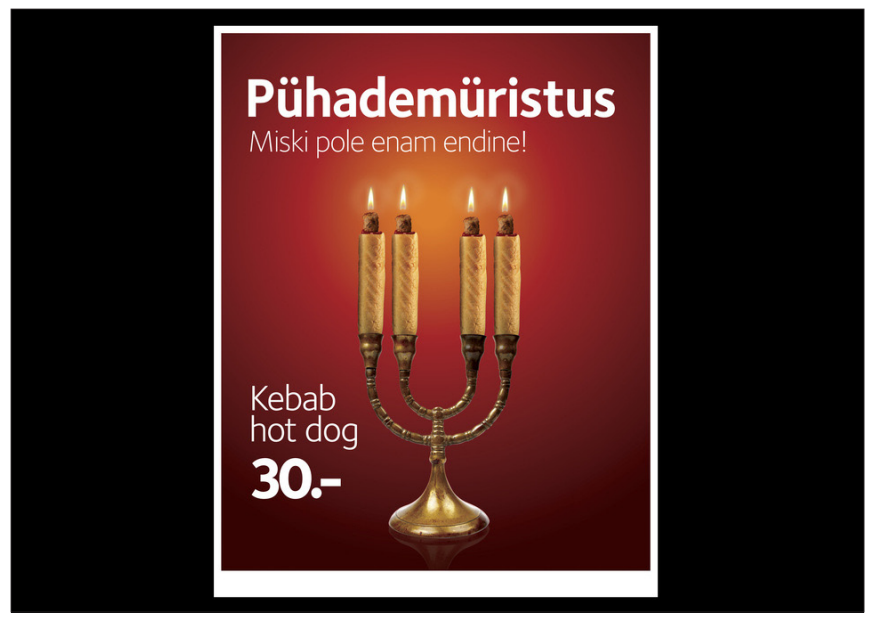

Foto 4. Statoili reklaam. 
lubatu ka reaalselt, aspekt, mida kaldutakse tihtipeale alahindama, kui kasutatakse avalikkusele suunatud sõnumis kujundkeelseid ekspressiivseid väljendeid.

Järgmine näide (foto 4) annab aimu äärmiselt mitmekihilisest sõnumi edastamise võimalusest reklaamis. Erinevalt eeltoodutest ei ole fraseologism (Pühade müristus) antud juhul otseselt visualiseerimise allikaks. Kuigi eesti fraseologismide andmebaasis leidub vaid üks vastava väljendi üleskirjutus (aastast 1966) ja see mõjub mõneti arhailisena, kohtab retoorilist hüüatust $O h$ sa püha(de) müristus! keelekasutuses sagedasti tänapäevalgi. Kui vaadata olulisimaid varaseimaid leksikograafilisi allikaid, puudub antud väljend nii F. J. Wiedemannil kui ka Andrus Saarestel. Eeldatavasti on tegemist saksa päritolu interjektsiooniga (vrd Donner und Blitz! 'välk ja pauk'). Tänapäeva kirjakeelset esinemust kinnitab siiski fikseering eesti kirjakeele seletussõnaraamatus: Sa püha müristus! (märkega 'imestusavaldus'). Nimisõna müristus on nimisõnaline tuletis verbist müristama, mille üks tähendusi on seotud kõuemürinaga. Imestamise väljendusena on aluseks tõenäoliselt just see assotsiatiivne tähendusseos. Võimalik, et autorid on visuaalsel kujutamisel lähtunud sõnast "püha", ${ }^{25}$ seda enam, et tegu on jõulureklaamiga. Reklaamis on pandud kokku esmapilgul täiesti sobimatud seigad. Hüüatus peaks märkima reaktsiooni soodsale pakkumisele kui millelegi enneolematule või ennekuulmatule - sellele osutab täpsustav repliik, mis märgib olulist muutumist võrreldes vanade (nn heade) aegadega (Miski pole enam endine!). Teiselt poolt ilmneb see 'enam mitte endine' kummastavalt mõjuvast illustratsioonist. Nimelt kasutatakse visualiseerimiseks eset, mis stiililt meenutab usundiliselt kõnekat, juudikultuuri kuuluvat menoraad. Küll tehakse seda oma sõnumi edastamiseks karikatuurses võtmes - originaalis seitsmeharulist küünlajalga kujutatakse neljaharulisena, seejuures on küünalde asemel kebab hot dogid (mis sealsamas pildi kõrval ka kirjas on). Ühe kultuuri sümbolist on saadud inspiratsiooni laialt tuntud, ent siiski teistlaadsest kultuuriruumist pärinevate ilmingute - idamaist päritolu liharoog (kebab) ja ameerikalik kiirtoit (hot dog) - reklaamimiseks. Kuna tegemist oli jõulukampaaniaga (aastast 2008), lisandub veel üks kummastav seik: teadupärast ei

${ }^{25}$ Fraseologismi asemel ühe tema komponendi visualiseerimine osutab fraseologismi mõtestamise eelmainitud eripärale - tõlgendamisel võidakse tugineda ühe kindla lekseemiga seotud assotsiatiivsetele seostele. Selle seose aluseks võib olla lihtsalt sõna mitmetähenduslikkus. 
tähista juudid jõule. Seega on tegemist teksti ja pildi erisugustele, tugevalt vastuolulistele seostele rajaneva reklaamiga, mille erinevaid kihte ei pruugi esmapilgul hoomatagi. Kuigi reklaamitav ettevõte on taas välismaist päritolu (Statoil), on kohaliku turu jaoks kasutatud eestimaist reklaamifirmat, kelle loominguline lähenemisnurk balansseerib poliitkorrektsuse piirimail.

Viies reklaam on näide sellest, kuidas väljendi tähendusega mängides võib tahtmatult hoopis ebaõnnestuda. Karu rahvapärane eufemistlik nimetus mesikäpp on ühtlasi populaarse kodumaise kommisordi nimi. Reklaami eesmärk oli teadvustada tarbijat vana toote väljalaskmisest uuel kujul - jäätisena. Reklaamlause "Tegime Mesikäpa külmaks!” on siinkohal aga kahetähenduslik. Nimelt tähendab verbaalne püsiühend \{kedagi\} külmaks tegema ülekantult 'kedagi maha lööma, tapma' (FS). Eesti fraseologismide andmebaasi andmetel pärineb see väljend sõjaaegsest kõnepruugist (näitetekstina Vaenlased tehti külmaks). Lühidalt ja löövalt mõeldu puhul ei võetud arvesse kujundliku tähendusplaani tekkimise võimalust. Ning nii kasutati tugevalt ekspressiivset väljendit, mida on seostatud ka vanglažargooniga, antud juhul lastele suunatud reklaamis. Seik, mis leidis ohtrat negatiivset vastukaja nii online-ajakirjanduses kui ka sotsiaalmeedias. Näidetena vaid mõned pealkirjad/tsitaadid:

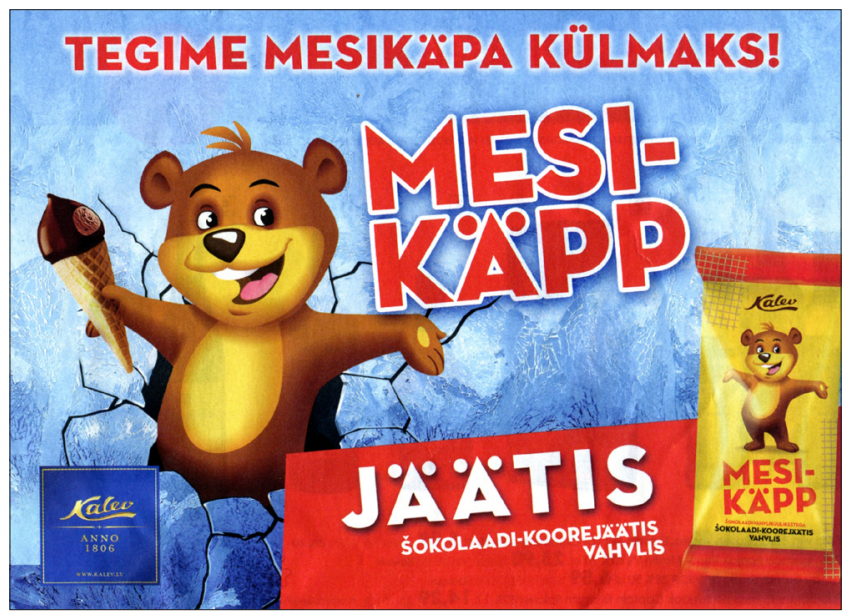

Foto 5. Kalevi reklaam. 
- Külmaks tehtud Mesikäpp batoonkingades (Eesti Päevaleht 2011).

- Kas reklaamlausest “Tegime Mesikäpa külmaks!” peab nii aru saama, et Kalev tunnistab end ühe mõmmi mõrvamises sü̈̈di? (Meiel 2011).

- Kalevi poolt turule toodud Mesikäpa jäätis on leidnud kajastamist tänavareklaamis, kust väikesed lapsedki saavad tähttähe haaval lugeda, et Mesikäpp on nüüd "külmaks tehtud". Vanglažargoonis tähendab kellegi külmaks tegemine maha löömist. Loodame siiski, et Mesikäpaga on kõik korras. (Vaene Mesikäpp tehti külmaks! - Vahvel.net 2011.)

Ehk olid ka ootamatud kriitilised reageeringud põhjuseks, miks reklaami eluiga tänavapildis jäi üürikeseks. Igal juhul on tegu ilmeka näitega, kuidas väljenditega oskamatult ümber käies võidakse endale (mitte tingimata tootele) teha hoopis negatiivset reklaami. Tunnustatud kohalik pikkade traditsioonidega ettevõte sai halvasti väljakukkunud tootepromomisega oodatust vastupidise tähelepanu.

Ka viimase näite puhul (foto 6) on taas tegu reklaamiga, mis kujutab endast teksti ja fraseoloogilise väljendi kombinatsiooni, mis ei ole esmapilgul hõlpsalt mõistetav. Tegelikult koosneb tekstiline pool koguni kahest väljendist (Saiast on siiber. Loodus kutsub.): \{millestki\} siiber olema 'millestki on kõrini, villand' (EKSS) ja loodus kutsub 'wc-sse minek' (EESS). Esimene väljend esindab peaasjalikult aastakümnete tagust noorteslängi (EKFA andmetel


1990. aastatest, tõenäoli-

Foto 6. EAS Turismiarenduskeskuse reklaam Tartu linna tänaval. A. Barani foto 2009. 
selt siiski varasem), mille täpsem päritolu jääb küll hämaraks, ${ }^{26}$ teisega on aga mõneti keerulisem. Eesti keeles on selline ütlus olnud olemas juba enne inglise keele pealetungi, seega ei saa seda pidada toortõlkeks inglise keelest - Mother nature is calling. ${ }^{27}$ Küll võib aga viimase mõjuga põhjendada väljendi nn uut tulemist just viimastel aastatel. Siinkirjutanule on küll teadmata, kas reklaami autorid adusid ka ütluse teist, iroonilisemat tähendust, ent igal juhul on õnnestunult suudetud ühitada visualisatsiooni kaudu kujundlik väljend ja sõnum. Sarnaselt mitme eelneva näitega, tõuseb reklaamisõnumit toetava visuaalia mõtestamisel tulu kohaliku kultuurikonteksti tundmisest. Kõnealuse reklaami puhul rakendati erinevaid multimeediavahendeid - lisaks tänavareklaamile ka telereklaami ja bänner-reklaami internetis. Viimasele klikkides avanes nn mäng, mis seisnes kursori ekraanil liigutamises (käsk Paku pardile saia!), mille tulemusena avanes põhisõnum (Puhka Eestis!), reklaami eesmärk oli elavdada kodumaist turismi. ${ }^{28}$

\section{Kokkuvõtteks}

Fraseologismide puhul on tavaks rääkida püsivusest, kinnistumisest, reprodutseeritavusest - seega on tegemist keeleüksusega, mille puhul välistuks justkui igasugune muutumine. Toodud näited reklaami ja fraseologismi koosesinemisest kujutavad endast mitmetähenduslikkusel põhinevaid semantilisi modifikatsioone, mille kõrval üksnes tühisel määral esineb ka vormilisi muudatusi. Niisugused keelemängulised kõrvalepõiked on fraseologismide reprodutseerimise loomulik osa. Teisalt alluvad fraseoloogilised väljendid hõlpsalt vastuvõtjate tõlgendustele, mida tõestavad inimeste selgitused fraseoloogia-alastes küsitlustes. Seega ei takista väljendi mittetundmine tingimata temast arusaamist. Just fra-

${ }^{26}$ Saksa päritolu "siiber" (der Schieber) üks tähendusi on Saareste andmetel 'ettelükatav klapp'; seega võiks üks väljendi mõtestamiseks tuge andev selgitus olla 'klapp on ees' (Saareste 3, 937).

$27 \mathrm{Vt}$ http://www.urbandictionary.com/define.php?term=mother\%20 nature\%20is\%20calling\&defid $=5566747(01.02 .2013)$.

${ }^{28}$ Antud reklaam oli osa pikemaajalisest kampaaniast, mille tegelaskujud vaheldusid. 2009. aastal väljatulnud reklaam tunnistati ka kohaliku reklaamituru üheks parimaks ehk Kuldmuna omanikuks. Reklaami kõnealuse versiooni leiab aadressilt http://www.tank.ee/kuldmuna/puhka_ eestis_250x250_part.swf (03.10.2012). 
seologismi kujundlikkus ehk piltlikkus on see, mis annab põhjuse rääkida erinevatest mõtestusvõimalustest - sõnaühendi töötlemisel rakenduvast visualiseerimisest. Selle aspekti uurimisel on võimalik lähtuda psühholingvistilisest uurimissuunast. Kujundlik väljend kutsub esile tunnetusliku tegevuse - tähenduse otsimise ja konstrueerimise. Kuigi fraseoloogia kasutamises on olulisel kohal kreatiivsus, saab mõistmine olla edukas juhul kui mõlemapoolselt adutakse laiemat konteksti, väljendugu see siis kontseptuaalsel või kultuurilisel tasandil. Teisalt: kuigi visualiseerimisest võib mõistmisel abi olla, võidakse seda võimalust kasutades ka kunstiliselt liialdada ja manipuleerida. Iseäranis ilmneb selline eesmärgipärase loomingulisuse olemus reklaaminduses. Kommunikatiiv-pragmaatilisest seisukohast on nende põhieesmärk äratada tähelepanu, panna vastuvõtjat süvenema ja dekodeerima visuaalselt kujutatut. Nagu toodud näidetest ilmnes, tehakse seda üldjuhul assotsiatiivsetele seostele tuginedes. Paraku ei võeta arvesse, et vastuvõtjal võib mõistmine toimuda teistlaadselt. Seega võib fraseologismi puhul rääkida keelemärgist, mis tunduvalt komplekssema ilminguna võimaldab erisugust mõtestamist. Reklaamides sagedasti ettetulev fraseologismide visualiseerimine on suurepärane näide pildi ja teksti põimumisest, mis ei ole muutumas, vaid on juba saanud valitsevaks. Oluliseks on saamas küsimus, kui suurel määral sõltub visualiseeritud tekstide mõistmine olemasolevast keelelisest pädevusest või on siinkohal olulisemad hoopis kognitiivne ja interaktiivne kompetents.

\section{Kirjandus}

Bachmann, Talis 2005. Reklaamipsühholoogia. Teine, täiendatud trükk. Tallinn: Kirjastus Ilo.

Baran, Anneli 2008. Fraseologismide semantilise teisititõlgendamise võimalikkusest. - Metslang, Helle; Langemets, Margit; Sepper, Maria-Maren (toim). Eesti Rakenduslingvistika Ühingu aastaraamat 4 / Estonian Papers in Applied Linguistics 4. Tallinn: Eesti Keele Sihtasutus, 17-33 (DOI: http://dx.doi.org/10.5128/ERYa4.02).

Baran, Anneli 2011. Fraseologismide semantika uurimisvõimalused. Doktoritöö. Tartu: Tartu Ülikooli Kirjastus.

Baranov, Anatoli; Dobrovolski, Dmitri 2008 = Баранов, А. Н.; Добровольский, Д. О. Аспекты теории фрразеологии. Studia philologica. Москва: Знак. 
Boers, Frank; Píriz, Ana María Piquer; Stengers, Hélène; Eyckmans, June 2009. Does pictorial elucidation foster recollection of idioms? - Language Teaching Research 13 (4), 367-382.

Burger, Harald 1973. Idiomatik des Deutschen. Unter Mitarbeit von Harald Jaksche. Tübingen: Niemeyer.

Burger, Harald 2003. Phraseologie. Eine Einführung am Beispiel des Deutschen. Berlin: Erich Schmidt.

Cacciari, Cristina; Glucksberg, Sam 1995. Imagining Idiomatic Expressions: Literal or Figurative Meanings? - Everaert, Martin; van der Linden, Erik-Jan; Schenk, André; Schreuder, Rob (toim). Idioms: structural and psychological perspectives. Hillsdale: Erlbaum, 43-56.

Crystal, David 2001. Language and the Internet. Cambridge: Cambridge University Press.

Dobrovolski, Dmitri 1997 = Dobrovol'skij, Dmitrij. Idiome in kognitiver Perspektive. Zur Begriffsbestimmung. - Skog-Södersved, Mariann (toim). Ethische Konzepte und mentale Kulturen 1. Auf der Suche nach ethischen Konzepten in Wortschatz und Phraseologie. Acta Universitatis Umensis, Umea Studies in the Humanities 139. Umeå: Umea University Press, 17-57.

Dobrovolski, Dmitri; Piirainen, Elisabeth 1996 = Dobrovol'skij, Dmitrij; Piirainen Elisabeth. Symbole in Sprache und Kultur Studien zur Phraseologie aus kultursemiotischer Perspektive. - Eismann, Wolfgang; Grzybek, Peter; Mieder, Wolfgang (toim). Studien zur Phraseologie und Parömiologie. Bochum: Brockmeyer.

Dobrovolski, Dmitri, Elisabeth Piirainen 2005 = Dobrovol'skij, Dmitrij; Piirainen, Elisabeth. Figurative language: cross-cultural and crosslinguistic perspectives. Current Research in the Semantics / Pragmatics Interface13. Amsterdam [etc.]: Elsevier.

Dobrovolski, Dmitri; Piirainen, Elisabeth 2009 = Dobrovol'skij, Dmitrij; Piirainen, Elisabeth. Zur Theorie der Phraseologie. Kognitive und Kulturelle Aspekte. Tübingen: Stauffenburg Verlag.

Dundes, Alan; Stibbe, Claudia A. 1981. The Art of Mixing Metaphors. A Folkloristic Interpretation of the Netherlandish Proverbs by Pieter Bruegel the Elder. FF Communications, 230. Helsinki: Suomalainen Tiedeakatemia.

EKFA = Baran, Anneli; Hussar, Anne; Õim, Asta; Õim, Katre (koost). Eesti kõnekäändude ja fraseologismide andmebaas 1998-2005. (http:// www.folklore.ee/justkui - 04.02.2013).

EKSS $=$ Eesti kirjakeele seletussõnaraamat I-VII. Tallinn: Eesti Keele Instituut 1988-2007.

EESS = Loog, Mai 1991. Esimene eesti slängi sõnaraamat. Tallinn: Mai Loog (http://www.eki.ee/dict/slang/ - 04.02.2013).

Farø, Ken 2006. Ikonographie, Ikonizität und Ikonizismus: Drei Begriffe und ihre Bedeutung für die Phraseologieforschung (http://www. linguistik-online.de/27_06/faroe.html (04.02.2013). 
Fiedler, Sabine 2010. Phraseology in a time of crisis. - Yearbook of Phraseology 1, 1-17 (http://dx.doi.org/10.1515/9783110222623.1.1).

Forceville, Charles 1994. Pictorial Metaphor in Advertisements. - Metaphor and Symbolic Activity 9 (1), 1-29 (http://dx.doi.org/10.1207/ s15327868ms0901_1).

FS = Õim, Asta 1993. Fraseoloogiasõnaraamat . Tallinn: Keele ja Kirjanduse Instituut.

Geeraerts, Dirk 2002. The interaction of metaphor and metonymy in composite expressions. - Dirven, René; Pörings, Ralf (toim). Metaphor and Metonymy in Comparison and Contrast. Cognitive Linguistic Research 20. Berlin; New York: Mouton de Gruyter, 435-465.

Gibbs, Raymond W. Jr. 1989. Understanding and Literal Meaning. - Cognitive Science 13, 243-251 (http://dx.doi.org/10.1016/03640213(89)90006-2).

Gibbs, Raymond W. Jr. 1994. The poetics of mind: figurative thought, language, and understanding. Cambridge [etc.]: Cambridge University Press.

Gibbs, Raymond W. Jr. 1998. The fight over metaphor in thought and language. - Cacciari, Cristina; Katz, Albert; Turner, Mark (toim). Figurative Language and Thought. Oxford: Oxford University Press, 88-118.

Gibbs, Raymond W. Jr. 2002. A new look at literal meaning in understanding what is said and implicated. - Journal of Pragmatics 34 (4), 457-486 (http://dx.doi.org/10.1016/S0378-2166(01)00046-7).

Giora, Rachel 2003. On our mind: salience, context, and figurative language. Oxford: Oxford University Press.

Hallsteindóttir, Erla 2011. Aktuelle Forschungsfragen der deutschsprachigen Phraseodidaktik. - Linguistik online 47 (3) (http://www.linguistikonline.de/47_11/hallsteinsdottir.html - 04.02.2013).

Häcki Buhofer, Annelies 1999. Psycholinguistik und Phraseologie. - Fernandez-Bravo, Nicole; Behr, Irmtraud; Rozier, Claire (toim). Phraseme und typisierte Rede. Tübingen: Stauffenburg, 63-75.

Johnson, Mark 1978. The Body in the Mind. The bodily basis of meaning, imagination, and reason. Chicago : University of Chicago Press.

Kasik, Reet 2000. Reklaamikeel tekstiliigina. - Hennoste, Tiit (toim). Eesti keele allkeeled. Tartu ülikooli eesti keele õppetooli toimetised 16. Tartu: Tartu ülikool, 111-127.

Krikmann, Arvo 2004. Koestler, Raskin, Attardo ja teised: Linguistiliste huumoriteooriate uuemaist arenguist. Reetor 4. Tartu: Eesti Kirjandusmuuseum, folkloristika osakond, Eesti Kultuuriloo ja Folkloristika Keskus.

Laaniste, Mari 2005. Piltide ja kirja keelest. - Keel ja Kirjandus 8, 617-629. Lakoff, George 2007. The contemporary theory of metaphor. - Evans, Vyvyan; Bergen, Benjamin K.; Zinken, Jörg (toim). The cognitive linguistics reader. London \& Oakville: Equinox, 267-315. 
Leičik, Vladimir 2006 = Лейчик, Владимир Моисеевич 2006. Язык рекламы в контексте глобализации и этнизации. Г. П. Нещименко (отв. ред.) Глобализация - этнизация: Этнокультурные и этноязыковые процессы: в 2-х кн. Москва: Наука, Кн. 1, 447-475.

Levorato, Maria Chiara; Cacciari, Cristina 1999. Idiom Comprehension in Children: Are the Effects of Semantic Analysability and Context Separable? - European Journal of Cognitive Psychology, 11 (1), 51-66 (http://dx.doi.org/10.1080/713752299).

Lotman, Juri 1981 = Лотман, Юрий Михайлович. Rhetoric. - Cтруктура и семиотика художественного текста. Труды по знаковым системам XII. Тарту: Тартуский государственный университет, $8-28$.

Metslang, Helle 1993. Verbitarind ajatähendust väljendamas. Virittäjä. Kotikielen seuran aikakauslehti 97, 203-221 (http:// www.kotikielenseura.fi/virittaja/hakemistot/jutut/1993_203.pdf 04.02.2013).

Mieder, Wolfgang 2008. "Proverbs speak louder than words". Folk wisdom in art, culture, folklore, history, literature, and mass media. New York: Peter Lang Publishing.

Naciscione, Anita 2010. Visual representation of phraseological image. Kuiper, Koenraad (toim). Yearbook of Phraseology 1. Kemptnen: De Gruyter Mouton, 19-43 (http://dx.doi.org/10.1515/9783110222 623.1.19).

Nayak, Nandini P.; Gibbs, Raymond W. Jr. 1990. Conceptual knowledge in the interpretation of idioms. - Journal of Experimental Psychology: General 119 (3), 315-330 (http://dx.doi.org/10.1037//00963445.119.3.315).

Permjakov, Grigori 1968 = Пермяков, Григорий Львович. Избранныле пословицы и поговорки народов Востока. Москва: Наука.

Röhrich, Lutz 1973. Lexikon der sprichwörtlichen Redensarten. Freiburg: Herder.

Röhrich, Lutz 1978. Sprichwörtliche Redensarten in bildlichen Zeugnissen. Mieder, Wolfgang (toim). Ergebnisse der Sprichwörterforschung. Europäische Hochschulschriften 192. Bern: Verlag Peter Lang, 87-107.

Saareste, Andrus 1958-1963. Eesti keele mõisteline sõnaraamat I-VI. Stockholm: Vaba Eesti.

Sarapik, Virve 1998. Punane. Sõna ja värv. - Sator 1. Artikleid usundi- ja kombeloost. Tartu: Eesti Keele Instituut, 7-37 (http://www.folklore. ee/rl/pubte/ee/sator/sator1/sator1-1.pdf - 04.02.2013).

Saussure, Ferdinand de 1966. Course in General Linguistics. New York: McGraw-Hill Book Company.

Szczepaniak, Renata; Lew, Robert 2011. The role of imagery in dictionaries of idioms. - Applied Linguistics 32 (3), 323-347 (http://dx.doi. org/10.1093/applin/amr001). 
Tendahl, Markus, Raymond W. Gibbs Jr. 2008. Complementary perspectives on metaphor: Cognitive linguistics and relevance theory. - Journal of Pragmatics 40 (11), 1823-864 (http://dx.doi.org/10.1016/j. pragma.2008.02.001).

Torop, Peeter 2008. Multimeedialisus. - Keel ja Kirjandus 8/9, 721-734 (http://keeljakirjandus.eki.ee/721-734.pdf - 04.02.2013).

Vakkur = Vana kirjakeele korpus (http://www.murre.ut.ee/vakkur/Korpused/ korpused.htm - 01.02.2013)

Varga, Éva 2010. (K)ein Grund sum Lachen! Phraseologische Modifikation in der Werbesprache. - Litovkina, Anna T.; Barta, Péter; Daczi, Margit (toim). Linguistic Shots at Humour. Humour and Culture 1. Kraków: Tertium, 209-226.

Vinogradov, Viktor 1947 = Виноградов, Виктор Владимирович. Об основных типах фразеологических единиц в русском языке. А. А. Шахлатов. 1864-1920. Сборник статей и материалов. Под редакцией С. П. Обнорского. Труды комиссии по истории Академии наук СССР; вып. 3. Москва; Ленинград: Изд-во Академии наук ССCP, 339-364.

Wiedemann, Ferdinand Johann 1973. Eesti-saksa sõnaraamat. Neljas, muutmata trükk teisest, Jakob Hurda redigeeritud väljaandest. Tallinn: Valgus.

\section{Keelenäidete internetiallikad}

Eesti Päevaleht 2011. http://www.epl.ee/news/melu/kulmaks-tehtudmesikapp-batoonkingades.d?id=51300222 -05.02 .2013 .

Fazer 2012. http://mustleib.fazer.ee/?utm_source=delfi.ee\&utm medium=sitehat_banner\&utm_campaign $=$ must_leib -05.02 .2013 .

HenriJääger 2008. http://reklaam.postimees.ee/?op=body\&id=162\&cid=100\&cgid -05.02 .2013 .

Meiel 2011. http://twitter.com/\#!/kaupomeiel/status/82166954776989696 -05.02 .2013 .

Vahvel.net 2011. http://vahvel.net/showthread.php?131744-VaeneMesik\%E4pp-tehti-k\%FClmaks!\&highlight=mesik\%E4pp 05.02.2013. 


\section{Summary}

\section{On the Role of Visualisation in Understanding Phraseologisms on the Example of Commercials}

Keywords: phraseologisms, iconicity, mental lexicon, iconic motivation, figurativeness

Phraseologisms are linguistic units characterised by figurativeness or usage of metaphors. But what exactly is figurativeness? In the case of a linguistic unit, it is a quality instigating visual imagery. So, the direct meaning of a great part of phraseologisms is so figurative that we can easily visualise it. It is obvious that these individual visualisations help us understand an unfamiliar expression. The fact that while interpreting phraseologisms, language users may consciously proceed from mental images, is also confirmed by psycholinguistic experiments. This article dwells upon visualisation of metaphorical expressions as a means of conveying messages in advertisements and their reception or interpretation. 


\section{MAAILM ja \\ MULTITASKING}

\section{Koostanud ja toimetanud MARE KÕIVA}

http://www.folklore.ee/rl/pubte/ee/cf/multi

ISBN 978-9949-544-01-1

Tartu 2014

Trükis ilmunud:

MAAILM ja MULTITASKING. Tänapäeva folkloorist 10.

Tartu 2014

Sarja peatoimetaja: Eda Kalmre

Kogumiku koostaja ja toimetaja: Mare Kõiva

Keeletoimetaja: Asta Niinemets

Kaanekujundus: Lilli-Krõõt Repnau

Küljendus: Diana Kahre

HTML: Diana Kahre

Trükist toetasid: teadusteema SF 0030181s08, ETF grant nr 8137 ja IUT22-5 ning Eesti Kultuurkapital.

E-raamatu valmimist toetas: EKKM14-344 Eesti keele, kultuuri ja folkloori kasutusalade laiendamine ja tutvustamine elektroonilistel infokandjatel.
(C) Mare Kõiva
(C) autorid
(C) EKM Teaduskirjastus 2014 